\title{
Ultrastructural Changes in the Kidney Cortex of Rats Treated with Lead Acetate
}

\author{
Cambios Ultraestructurales en la Corteza Renal de Ratas Tratadas con Acetato de Plomo
}

Deveci, E.; Söker, S.; Baran, Ö.; Tunik, S.; Ayaz, E. \& Deveci, S.

DEVECI, E.; SÖKER, S.; BARAN, Ö.; TUNIK, S.; AYAZ, E. \& DEVECI, S, Ultrastructural changes in the kidney cortex of rats treated with lead acetate. Int. J. Morphol., 29(3):1058-1061, 2011.

SUMMARY: The purpose of this study was to investigate the ultrastructural effects of lead on the kidney cortex of rats. Wistar Albino rats (180-200g body weight) were divided into a controlled and lead acetate-exposed group. Rats received lead acetate at 500 $\mathrm{ppm}$ in their drinking water for 60 days. Both groups were fed with the same standard food, but lead acetate was added to the drinking water. During the experimental period, blood samples were taken from the abdominal aorta of the anesthetised animals. At the end of exposure, body weight and blood lead levels were measured. The kidney tissue samples were prepared and analyzed by light and transmission electron microscopy. Cortical renal tubules show various degenerative changes with focal tubular necrosis invaded by inflammatory cells. The ultrastructural alterations found in lead acetate-treated rats were a diminution in the amount of filtration slits, increased fusion of foot processes in epithelial cells of the glomeruli, increase of lysosomal structures and pinocytic vesicles as well as large mitochondria in proximal tubule cells.

KEY WORDS: Lead acetate; Kidney cortex; Ultrastructural changes.

\section{INTRODUCTION}

Lead $(\mathrm{Pb})$ is a toxic metal that induces a broad range of physiological, biochemical and neurological dysfunctions in humans (Deveci, 2006). Lead is a widely distributed and ubiquitous environmental pollutant, shown to be, representing a high toxicological and ecotoxicological risk. Many animal studies have shown that lead is capable of causing oxidative stress in the kidney, liver, and brain (Ercal et al., 1996; Patra et al., 2001). The absorbed Pb is conjugated in the liver and passed to the kidney, where a small quantity is excreted in urine and the rest accumulates in various body organs, affecting and affects many biological activities at the molecular, cellular and intercellular levels, which may result in morphological alterations that can remain even after $\mathrm{Pb}$ levels have fallen (Jarrar, 2003; Sidhu \& Nehru, 2004; Taib et al., 2004; Flora et al., 2006). The kidney is a sensitive target organ for lead exposure. The purpose of this study is to investigate the ultrastructural effect of lead acetate in the kidney cortex.

\section{MATERIAL AND METHOD}

Animals. Wistar rats ( 9 weeks old, $180-200 \mathrm{~g}$ body weight) used in these trials were divided into two groups of 30 animals each (control group and experimental group). Animals of the experimental group were given drinking water containing $500 \mathrm{ppm}$ lead acetate for a period of 2 months. The rats were obtained from the Department of Medical Science Application and Research Centre of Dicle University. All the animals were individually housed in stainless steel cages at room temparature. The animals had free access to standard laboratory rat pellet and water. The animals were sacrificed by decapitation under ether anesthesia, and kidney tissue were quickly removed.

Histopathological analysis. For sample preparation under light microscopy after fixation of tissues by formaldehyde $10 \%$ solution, they were directly dehydrated in a graded serious of ethanol and embedded in paraffin. Thin sections, 5-6 micrometres, were cut by using a microtome and stained 
with Hematoxylen and Eosin and examined by using a light microscope. Some tissue fragments were fixed in $2.5 \%$ of gluteraldehyde and in $0.1 \mathrm{~m}$ sodium cacodylate buffer at $48 \mathrm{C}$ and $\mathrm{p} 7.2$ for $24 \mathrm{~h}$, washed $0.1 \mathrm{~m}$ buffer and part fixed in sodium tetroxide $0.2 \mathrm{~m}$ buffer for $1 \mathrm{~h}$ and embedded into the CY96 araldite. Thin sections (70-nm thick) were stained with lead citrate-uranyl acetate, examined and photographed under Zeiss Electron microscope 9S.

Blood sample collection. The animals were anesthetised with diethylether, and blood samples were collected via intracardiac puncture, using heparin as anticoagulant. The whole blood samples were maintained at $48 \mathrm{C}$ for blood concentration. Blood lead levels were analyzed,by using an atomic absorption spectrophotometer.

Statistics. The experimental data were evaluated by means of the Student's t -test. The blood values were expressed. The effects on body weight of a rat were exposed to 500 ppm lead acetate in drinking water were also determined.The blood lead values were expressed as $\mathrm{mg} / \mathrm{dL}$ of the whole blood.

\section{RESULTS}

Body weights of lead exposed group declined progressively with significant decline for a period of 2 months of lead exposure $(\mathrm{P}<0.05)$ in comparison to control rats. Blood lead level of rats after prolonged consumption of water enriched with lead acetate significantly exceeded those observed in controls and reached $28.40 \mathrm{mg} / \mathrm{dL}$. After 60 days of exposure to lead acetate, a significant increase of lead concentration was observed in the blood $(\mathrm{P}<0.01)$ (Table I).

Table I. Body Weight and Blood Value were measured.

\begin{tabular}{lcc}
\hline Group & \multicolumn{2}{c}{ Variable } \\
\cline { 2 - 3 } & Body weight & Blood mg/dL \\
\hline Control (n=10) & $200.30 \pm 3.70$ & $1.82 \pm 1.05$ \\
Experimental $(\mathbf{n = 1 0})$ & $160.20 \pm 4.05$ & $28.40 \pm 1.04$ \\
\hline
\end{tabular}

In our study, histopathologic comparison between the sections of the control group and experiment group subjected to lead acetate was made (Table I). In the rat lead acetate for 60 days, there were obvious areas of tubular necrosis, vascular changes with interstitial edema and glomerular fibrosis and cell hypertrophy (Fig. 1).

Cortical renal tubules show various degenerative changes with focal tubular necrosis invaded by inflammatory
cells.The control kidneys showed no evidence of glomerular, tubular or interstitial injury (Fig. 2). Areas of the renal cortex containing a glomerulus and associated tubules were selected for examination by electron microscope. The ultrastructural alterations found in lead-treated rats showed a diminution in the amount of filtration slits, increased fusion of foot processes in epithelial cells of the glomerulus, and slight thickening of the glomerular basement membrane (Fig. 3).

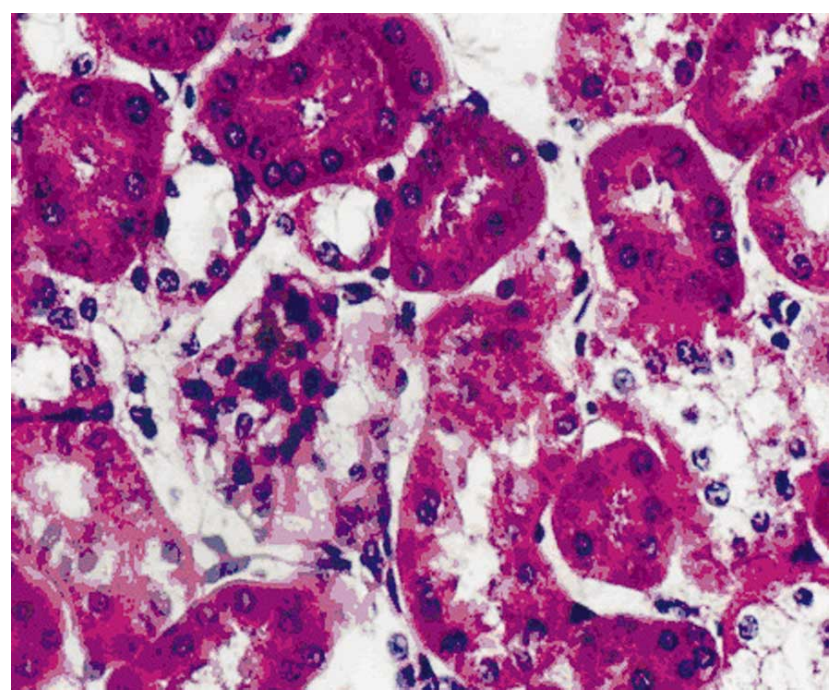

Fig. 1. In the kidney cortex tubular necrosis, vascular changes with interstitial edema and glomerular fibrosis and cell hypertrophy (Hematoxylen- Eosin, original magnification X 82).

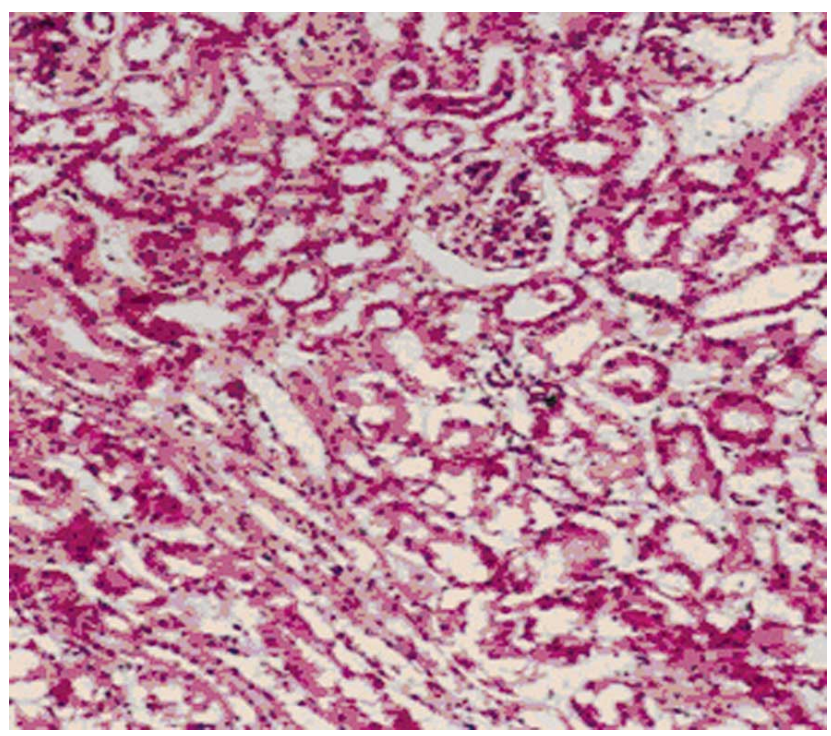

Fig. 2. The kidney cortex showed no evidence of glomerular, tubular or interstitial injury (Hematoxylen-Eosin original magnification X 41).

Ultrastructural changes included matrix vacuolation, swelling and condensation of mitochondria. Cisternae of endoplasmic reticulum were dilated. Irregular lysosomes 
containing dense material,some of which had a laminated appearance, were numerous in many cells. Electron microscopy showed cytoplasmic vacuolation of the proximal tubules, mitochondrial swelling and coagulative necrosis in the rat exposed to lead acetate for 60 days (Fig. 4).

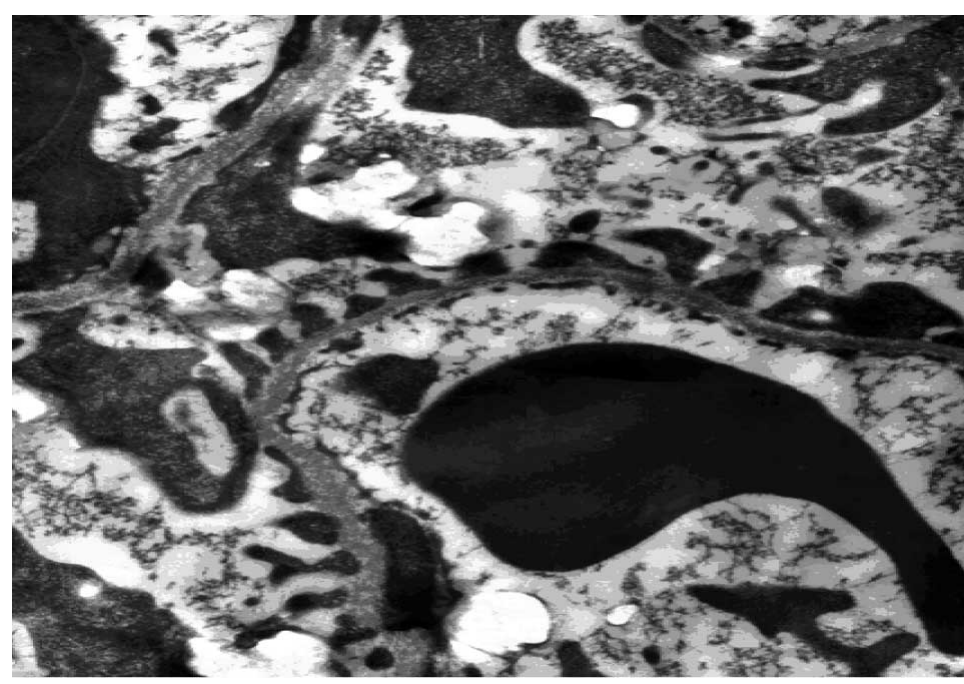

Fig. 3. A diminution in the amount of filtration slits, increased fusion of foot processes in epithelial cells of the glomerulus (Uranyl acetate-lead citrate X 7600).

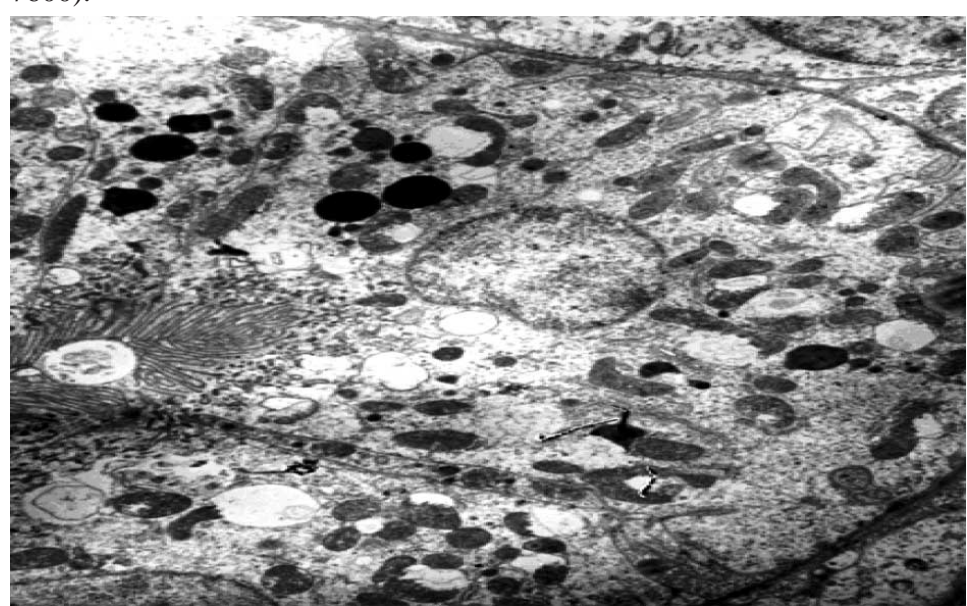

Fig. 4. Electron microscopy showed cytoplasmic vacuolation of the proximal tubules, mitochondrial swelling and coagulative necrosis (Uranyl acetate-lead citrate X 7200).

\section{DISCUSSION}

Lead is one of the most important metals that pollute the natural environment due to man's impact. Acute and chronic $\mathrm{Pb}$ exposure both cause histological lesions in the kidney. These lesions are characterized by the presence of intranuclear inclusion bodies, which were induced at significantly lower concentrations than those associated with clinical toxic manifestations (Alden \& Khan, 2002).
Another histological indication of $\mathrm{Pb}$ toxicity in the rat kidney is the karyomegaly of tubular cells (Payne \& Saunders, 1978). Tubular, interstitial and glomerular damage are also characteristic renal lesions due to $\mathrm{Pb}$ toxicity. Tubular changes occur earlier than glomerular and interstitial changes, including development of pathognomonic intranuclear inclusions in the renal tubular epithelium (Jarrar; McGavin \& Zachary, 2007).

Our data showed clear renal lesions associated with chronic $\mathrm{Pb}$ toxicity and characterized by varying degrees of damaged glomeruli, and degenerated proximal tubules in all intoxicated rats in the form of karyomegaly and intranuclear inclusion formation. Nearly, $70 \%$ of intoxicated rats showed necrotic cortical tubules. Ceruti et al. (2002) showed a correlation between histological alterations and $\mathrm{Pb}$ concentration. Inclusion bodies rapidly disappear with chelation therapy (Alden \& Khan). This may explain the improvement of histological findings in the kidneys, especially the number of cells exhibiting karyomegaly and intranuclear inclusions, in PbAc-intoxicated rats supplemented with VC. A previous work demonstrated that chronic lead exposure caused changes in the extracellular protein expression and ultrastructural modifications such as a decrease in the thickness of the glomerular basal membrane in rat kidney (Sanchez et al., 2001). The prominent histopathological changes in lead acetate exposed kidney include thickening of glomerular basement membrane, degeneration of tubular epithelial cells, atherosclerotic changes and disintegration of brush border membrane, which may be responsible for the observed renal dysfunction.

The histopathological lesions described above conform to the generally accepted classification of tubulo-interstitial nephritis. The pattern which emerges in the $\mathrm{Pb}$-exposed rat is that of a progressive nephrotic syndrome affecting first the tubules and surrounding blood vessels and connective tissue with secondary to a glomerular lesion involving the epithelial cells and the capillary loop. In conclusion, Lead acetate toxicity results in alterations in the renal cortex glomerular cells or tubular, which could play an important role in renal dysfunction. 
DEVECI, E.; SÖKER, S.; BARAN, Ö.; TUNIK, S.; AYAZ, E. \& DEVECI, S. Cambios ultraestructurales en la corteza renal de ratas tratadas con acetato de plomo. Int. J. Morphol., 29(3): 1058-1061, 2011.

RESUMEN: El propósito de este estudio fue investigar los efectos ultraestructurales del plomo en la corteza renal. Ratas Wistar albinas (180-200g de peso corporal) fueron divididas en grupo control y grupo experimental. Las ratas recibieron 500 ppm de acetato de plomo en el agua potable durante 60 días. Ambos grupos fueron alimentados con el mismo alimento estándar, pero acetato de plomo se le añadió al agua potable al grupo experimental. Durante el período experimental, se tomaron bajo anestesia muestras sanguíneas desde la parte abdominal de la aorta. Al final de la exposición, fueron medidos el peso corporal y los niveles de plomo en la sangre. Fueron preparadas las muestras de tejido renal y se analizaron mediante microscopía de luz y electrónica de transmisión. Los túbulos renales corticales mostraron varios cambios degenerativos con necrosis tubular focal invadida por células inflamatorias. Las alteraciones ultraestructurales encontradas en las ratas tratadas con acetato de plomo correspondieron a una disminución en la cantidad de ranuras de filtración, aumento de la fusión de los procesos podales en las células epiteliales de los glomérulos, aumento de la estructura lisosomal y las vesículas pinocíticas, así como grandes mitocondrias en las células del túbulo proximal.

PALABRAS CLAVE: Acetato de plomo; Corteza renal; Cambios ultraestructurales.

\section{REFERENCES}

Alden, C. L. \& Khan, K. N. M. Kidney. In: Handbook of Toxicologic Pathology. Haschek, W. M. (Ed.). 2nd Ed. San Diego, Academic Press, 2002. pp.255-336.

Ceruti, R.; Ghisleni, G.; Ferretti, E.; Cammarata, S.; Sonzogni, O. \& Scanziani, E. Wild rats as monitors of environmental lead contamination in the urban area of Milan, Italy. Environ. Pollut., 117(2):255-9, 2002.

Deveci, E. Ultrastructural effects of lead acetate on brain of rats. Toxicol. Ind. Health, 22(10):419-22, 2006.

Ercal, N.; Treeratphan, P.; Hammond, T. C.; Matthews, R. H.; Grannemann, N. H. \& Spitz, D. R. In vivo indices of oxidative stress in lead-exposed C57BL/6 mice are reduced by treatment with meso-2,3-dimercaptosuccinic acid or N-acetylcysteine. Free Radic. Biol. Med., 21(2):157-61, 1996.

Flora, S. J. S.; Flora, G. \& Saxena, G. Environmental occurrence, health effects and management of lead poisoning. In: Lead: chemistry, analytical aspects, environmental impact and health effects. Casas, J. S. \& Sordo, J. (Eds.). Amsterdam, Elsevier Science, 2006. pp.158-228.

Jarrar, B. M. Histological and histochemical alterations in the kidney induced by lead. Ann. Saudi Med., 23(1-2):105, 2003.

McGavin, M. D. \& Zachary, J. F. Pathologic basis of veterinary disease. $4^{\text {th }}$ ed. St. Louis, Mosby, 2007. pp.654-5.
Patra, R. C.; Swarup, D. \& Dwivedi, S. K. Antioxidant effects of alpha tocopherol, ascorbic acid and L-methionine on lead induced oxidative stress to the liver, kidney and brain in rats. Toxicology, 162(2):81-8, 2001.

Payne, B. J. \& Saunders, L. Z. Heavy metal nephropathy of rodents. Vet. Pathol. Suppl., 15(5):51-87, 1978.

Sánchez, S.; Pérez Aguilar, R.; Genta, S.; Aybar, M.; Villecco, E. \& Sánchez Riera, A. Renal extracellular matrix alterations in lead-treated rats. J. Appl. Toxicol., 21(5):417-23, 2001.

Sidhu, P. \& Nehru, B. Lead intoxication: Histological and oxidative damage in rat cerebrum and cerebellum. $J$. Trace Elem. Exp. Med., 17(1):45-53, 2004.

Skerfving, S. \& Bergdahl, I. A. Handbook on the Toxicology of Metals. $3^{\text {rd }}$ ed. Amsterdam, Academic Press, 2007. pp.599-643.

Taib, N. T.; Jarrar, B. M. \& Mubarak, M. Ultrastructural alterations in hepatic tissues of white rats (Rattus norvegicus) induced by lead experimental toxicity. Saudi J. Biol. Sci., 11(1):11-20, 2004.

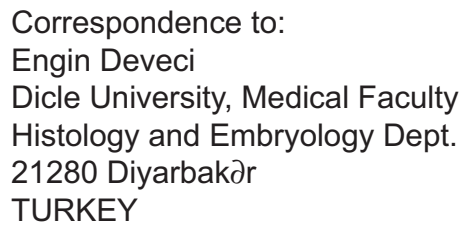

Received: 01-04-2011 Accepted: 02-05-2011

Email: engindeveci64@gmail.com 